\title{
Organic carbon in soils with different systems of use in Tacarimena Yopal, Colombia
}

\section{Carbono orgánico en suelos con diferentes sistemas de uso en Tacarimena Yopal, Colombia}

\author{
Blanca N. Carvajal-Agudelo; ${ }^{1}$ Hernán J. Andrade 2
}

\begin{abstract}
IIng. Forestal, M.Sc. Universidad Nacional Abierta y a Distancia - UNAD, Grupo de Investigación CAZAO. Yopal - Casanare, Colombia; e-mail: blanca.carvajal@unad. edu.co; (D) https://orcid.org/0000-0002-3848-8959

${ }^{2}$ Ing. Agrónomo, M.Sc., Ph.D. Universidad del Tolima, Facultad de Ingeniería Agronómica, Grupo de Investigación PROECUT. Ibagué - Tolima, Colombia; e-mail: hjandrade@ut.edu.co; (D) https://orcid.org/0000-0002-3398-294X
\end{abstract}

How to cite: Carvajal-Agudelo, B.N.; Andrade, H.J. 2021. Organic carbon in soils with different systems of use in Tacarimena Yopal, Colombia. Rev. U.D.C.A Act. \& Div. Cient. 24(1):e1921. http://doi.org/10.31910/rudca.v24.n1.2021.1921

Open access article published by Revista U.D.C.A Actualidad \& Divulgación Científica, under Creative Commons License CC BY-NC 4.0

Official publication of the Universidad de Ciencias Aplicadas y Ambientales U.D.C.A, University, Accredited as a High-Quality Institution by the Colombian Ministry of Education.

Received: February 1, $2020 \quad$ Accepted: April 16, $2021 \quad$ Edited by: Ingeborg Zenner de Polanía

\begin{abstract}
Soil is an important carbon reservoir as it can store twice the amount that atmosphere does and three times the biomass, which makes it a key component for climate change (CC) mitigation projects. It is important to know the potential of soil organic carbon storage (SOC) in the main uses of the soli and their expected dynamics due to potential use changes. SOCS is estimated in 7 of the dominant land use systems in the area of the study, with 5 replicas as follows: 1) banana with shade (SAF+banana); 2) cocoa with shade $(\mathrm{Ca}+\mathrm{S}) ; 3)$ citrus (C); 4) low silvopastoral system (SSPB); 5) high silvopastoral system (SSPA); 6) gallery forests (BG); and 7) bush forest (MM). SOC concentration was analyzed in samples composed of 25 soil sub-samples per plot, and the DA was estimated with the cylinder method in a simple per plot. All land uses studied can mitigate CC when storing SOC. BG was the system that showed the highest carbon storage. On the other hand, SAF+banana stored the least SOC $(72,7$ vs $33,4 \mathrm{Mg} / \mathrm{ha}$, respectively). Changes in land use can cause $\mathrm{CO}_{2}$ emissions or an addition in carbon fixation. Changes
\end{abstract}

in land use that increase SOC allow CC mitigation, which makes them feasible for funding, thus allowing an improvement in the livelihood of local producers.

Keywords: Bulk density; Emission; Mitigation; Ecosystem services; Agroforestry systems.

\section{RESUMEN}

El suelo es un reservorio importante de carbono, ya que puede almacenar el doble de lo contenido por la atmósfera y el triple de la biomasa. Esto lo constituye en un componente clave para proyectos de mitigación del cambio climático (CC). Es importante conocer el potencial de almacenamiento de carbono orgánico del suelo (COS) en los principales usos del suelo y su dinámica esperada, por potenciales cambios de uso. Se estima el COS en los siete de los sistemas de uso del suelo dominantes en el área de estudio, con cinco réplicas, así: 1) plátano con sombrío (SAF+plátano);2) cacao con sombrío $(\mathrm{Ca}+\mathrm{S}) ; 3)$ cítricos $(\mathrm{C}) ; 4)$ sistema silvopastoril 
bajo (SSPB); 5) sistema silvopastoril alto (SSPA); 6) bosques de galería (BG) y 7) mata de monte (MM). La concentración de COS fue analizada en muestras compuestas de 25 submuestras de suelo por parcela y la DA, se estimó con el método del cilindro en una muestra por parcela. Todos los usos del suelo estudiados pueden mitigar el CC al almacenar COS. El BG fue el sistema que presentó el mayor almacenamiento de carbono; por el contrario, el SAF+plátano almacenó el menor $\operatorname{COS}(72,7$ vs $33,4 \mathrm{Mg} / \mathrm{ha}$, respectivamente). Cambios de uso del suelo pueden causar emisión de $\mathrm{CO}_{2} \mathrm{O}$ adicionalidad en la fijación de carbono. Cambios de uso del suelo que incrementen el COS permiten la mitigación del CC, pudiendo ser susceptibles de financiamiento, lo que permite mejorar los medios de vida de los productores locales.

Palabras clave: Densidad aparente; Emisión; Mitigación; Servicios ecosistémicos; Sistemas agroforestales.

\section{INTRODUCTION}

Soil organic carbon (SOC) comes as a stage of the global cycle of this element and it is the largest sink of the biosphere, as it stores twice the amount of the atmosphere and three times what is found in biomass (1550 vs 750 vs 550Pg, respectively) (Bolin \& Sukumar, 2000). This way, SOC is an important sink against climate change, which is why many projects involve soil, such as afforestation and reforestation (Pearson et al. 2005). Knowing SOC reserves and the impact of land use systems in this edaphic feature allows managing the landscape in order to increase the offer of this ecosystem services. Carbon contained in biomass then moves into necromass due to tissue senescence. After that, part of that carbon becomes $\mathrm{CO}_{2}$ and it is released into the atmosphere, but another part merges with soil as organic matter, which contains carbon (FAO, 2017).

In addition to help as a climate change mitigator, SOC contributes to improve several biological and physicochemical properties of soil (Agostini et al. 2014). Those authors state that SOC favors soil aggregation and intervenes in pore distribution, favoring humidity retention, water and gas movement in the soil, increases cation exchange capacity, and tampon capacity over soil reaction $(\mathrm{pH})$. SOC also works as an energy source for heterotrophic organisms that live there.

Some carbon projects, such as Clean Development Mechanisms, and volunteer markets, have included soil as one of the components to generate a carbon addition and reduce emissions of greenhouse gases (GHG). The " 4 by 1000 " initiative, which identified the key role of soils for food security, the increase of carbon for soil fertility, came out recently in the COP21, adapting agriculture to climate change without compromising food production (https:// www.4p1000.org/es). On this matter, the Colombian State has started the implementation of the Colombian Strategy of Low Development on Carbon Emissions, identifying mitigation actions in the sector to reduce GHG and, with this same effort, generate environmental, social, and economic development in the rural area (Mendieta, 2011).
There are still several efforts to develop in order to take advantage of soils with high capacity to capture atmospheric carbon. These soils are representative of the valleys of the great rivers that are born in the Eastern Mountain Range and that, arriving in the plains, form alluvial fans with the material they transport. The foothill is a geographic area along the edge of this mountain range and it includes an ecological transition area between woodland forests and the savannah with sedimentary soils, with a higher fertility than the one for those deeper into the Orinoquia (IGAC, 2003).

Quantifying the ability of plants to store SOC for a long term is important for climate change mitigation and soil fertility improvement (Mathew et al. 2020). The goal of this study is to estimate SOC storage in the first $30 \mathrm{~cm}$ of depth in the most predominant land uses in the foothill of the municipality of Yopal, which covers 33.925ha (Alcaldía de Yopal, 2013). Likewise, it is intended to estimate what the change in SOC reserves could be if land use were altered, so that the potential of $\mathrm{CO}_{2}$ emissions or carbon additionality in this component could be tested. Results will work in the formulation of policies and projects that will include this ecosystem service as a way to improve the income of these rural citizens.

\section{MATERIALS AND METHODS}

Study area. located in the Corregimiento of Tacarimena, consisting of eight villages: El Nocuito, Manantiales, Sirivana, Palomas, La Calceta, La Manga, Tacarimena, and El Tiestal (Figure 1). The Corregimiento of Tacarimena has a surface of $339,25 \mathrm{~km}^{2}$, it is located to the southwest of the urban area of the Municipality of Yopal (Alcaldía de Yopal, 2013), between the coordinates $5^{\circ} 20^{\prime} 12^{\prime \prime}$

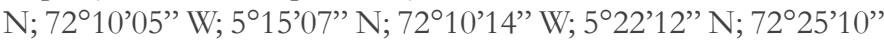
W; 5 $19^{\prime} 46^{\prime \prime} \mathrm{N} ; 72^{\circ} 15^{\prime} 07^{\prime \prime} \mathrm{W}$.

Soils in the area of study are located in the plains, composed of both fine and thick alluvial sediments that flow along the plain of the valley of Cravo Sur river. There, the local agricultural activity concentrates with plantain, cassava, and corn crops in traditional farming with some level of technology. This land unit is located in parallel with big hydric currents, which transport soils from the Eastern Mountain Range that renew periodically, thus having an incidence in fertility. The IGAC (2014) indicates that these soils are mildly acid, with a medium level of organic matter, low cation exchange capacity, medium to high base saturation, and natural fertility and limitations due to aluminum toxic content. The area consists of soils from the Fluventic Humic Dystrudepts-Typic Fluvaquents Association.

According to IDEAM (2018), weather in Yopal is warm-humid, with a mean annual precipitation of $2270 \mathrm{~mm}$, with a dry season (December to March), and a rainy season (April to October). The month with the highest mean precipitation is May, with $334 \mathrm{~mm}$, while the lowest is in January, with $9 \mathrm{~mm}$. Altitude of the area of study is located between 320 and $350 \mathrm{~m}$, and average temperature is around $26.9^{\circ} \mathrm{C}$. 


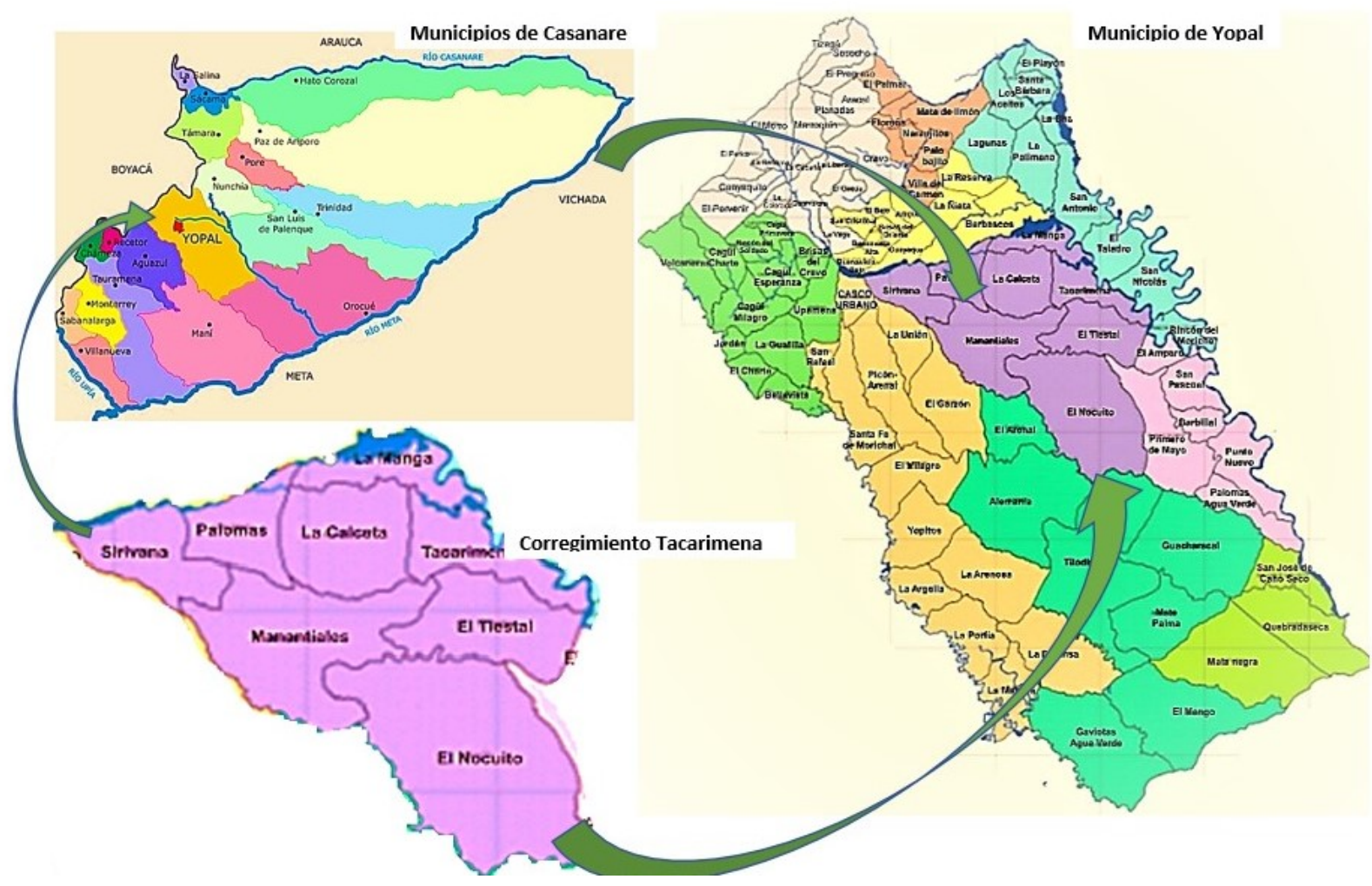

Figure 1. Location of the study area in Corregimiento of Tacarimena, municipality Yopal - Casanare, Colombia. Source: Alcaldía de Yopal (2013).

Experimental Design. A random design with seven land uses was utilized: 1) agroforestry systems (AFS) of plantain with shade (AFS+ plantain), 2) cocoa with shade (Co+S), 3) citrus (C), 4) low silvopastoral system (LSPS), 5) high silvopastoral system (HSPS), 6) gallery forests (GF), and 7) bush forest (BF), with five repetitions each. It was sought that these sampling units were in the same relief and showed similar soil and topography in order to avoid confused effect of treatments.

SOC estimation was performed at a $0-30 \mathrm{~cm}$ depth, based on two variables: SOC concentration and bulk density (BD) (GonzálezMolina et al. 2008; Alvarado et al. 2013). Gross fragment content was overlooked as it was too low ( $<5 \%$ volume). The first variable was estimated taking compound samples with 25 sub-samples per plot, which were studied in the soil laboratory from Universidad de los Llanos, using the Walkley \& Black method (1934). BD was estimated with the known method of the volume cylinder, which was calculated as the relation between the weight of the dry soil and the internal volume of the cylinder.

In the simulation of the land use change effect on SOC, the same $\mathrm{BD}$ was used as baseline (that of GF), to compare based on a same soil mass and not volume, which can change when compacted and thus alter the results, meaning that an increase effect on SOC storage due to $\mathrm{BD}$ was avoided. This possible change was estimated as the difference of SOC between the current and future land use that may occur, taking values to $\mathrm{CO}_{2}$, with the 44/12 relation, that corresponds to 3.67. Positive values suggest additional carbon fixation, whereas negative ones indicate $\mathrm{CO}_{2}$ emission.

Statistical Analysis. A variance analysis with seven systems of land use as treatments and five repetitions was used before validation of hypotheses and an average comparison test with the LSD Fisher test $(\alpha=0.05)$, using Infostat.

\section{RESULTS AND DISCUSSION}

Bulk density and organic carbon concentration in the soil. BD changed significantly $(\mathrm{p}<0.05)$ among land use systems. BD of soils differs statistically ( $\mathrm{p}<0.05$ ), among GF, C, AFS+ plantain, and HSPS. Thus, BD values between $1.33-1.48 \mathrm{~g} / \mathrm{cm}^{3}$ were found, being GF and BF soils the ones that show the highest value in this edaphic variable. On the contrary, HSPS, AFS+ plantain, and C had the lowest BD. This physical variable of soils turned out similar among the HSPS, AFS+ plantain, and C systems $\left(1.33-1.35 \mathrm{~g} / \mathrm{cm}^{3}\right)$, while $\mathrm{Co}+\mathrm{S}$, LSPS, and BF showed a BD between 1.40 and $1.43 \mathrm{~g} /$ $\mathrm{cm}^{3}$ (Figure 2). This tendency was also evinced in the findings of Andrade-Castañeda et al. (2016), who found values of BD for riparian forests, riparian forest margins, and agricultural matrix (rice, pastures), of $1.7,1.1$, and $1.0 \mathrm{~g} / \mathrm{cm}^{3}$, respectively. This contrasts with the findings of Andrade et al. (2018), where no BD differences in agriculture and riparian forests were detected in the basin of 
Combeima river (Ibagué, Colombia). Agricultural activities caused a reduction of $\mathrm{BD}$, which is possibly due to plowing activity on the soils. These results were not expected, since GF and BF have been the lowest anthropically intervened.

Peña et al. (2009) estimated BD between 1.16 and $1.66 \mathrm{~g} / \mathrm{cm}^{3}$ in Tauramena, Eastern mountain range in Casanare, Colombia, and indicate that these values are considered as a limitation for normal radical development. Rivera et al. (2013) studied the BD in the Llanos Orientales from Colombia, where values of $1.11-1.42 \mathrm{~g} / \mathrm{cm}^{3}$ were found, which are very similar to the findings of this current study. Literature reports that BD increases due to the activities of repetitive work with agricultural machinery. However, the study is performed in areas of natural vegetation and perennial agricultural zones, which are not affected by recurrent mechanization or work. Difference of BD in the soils of the systems studied can be attributed to the materials that compose these soils and not to possible deterioration due to the land use and management.

SOC concentration also showed statistical differences $(\mathrm{p}<0.05)$ among land use systems (Figure 2). This variable showed a range between 0.82 and $1.62 \%$ in the layer of 0 to $30 \mathrm{~cm}$, being the soils

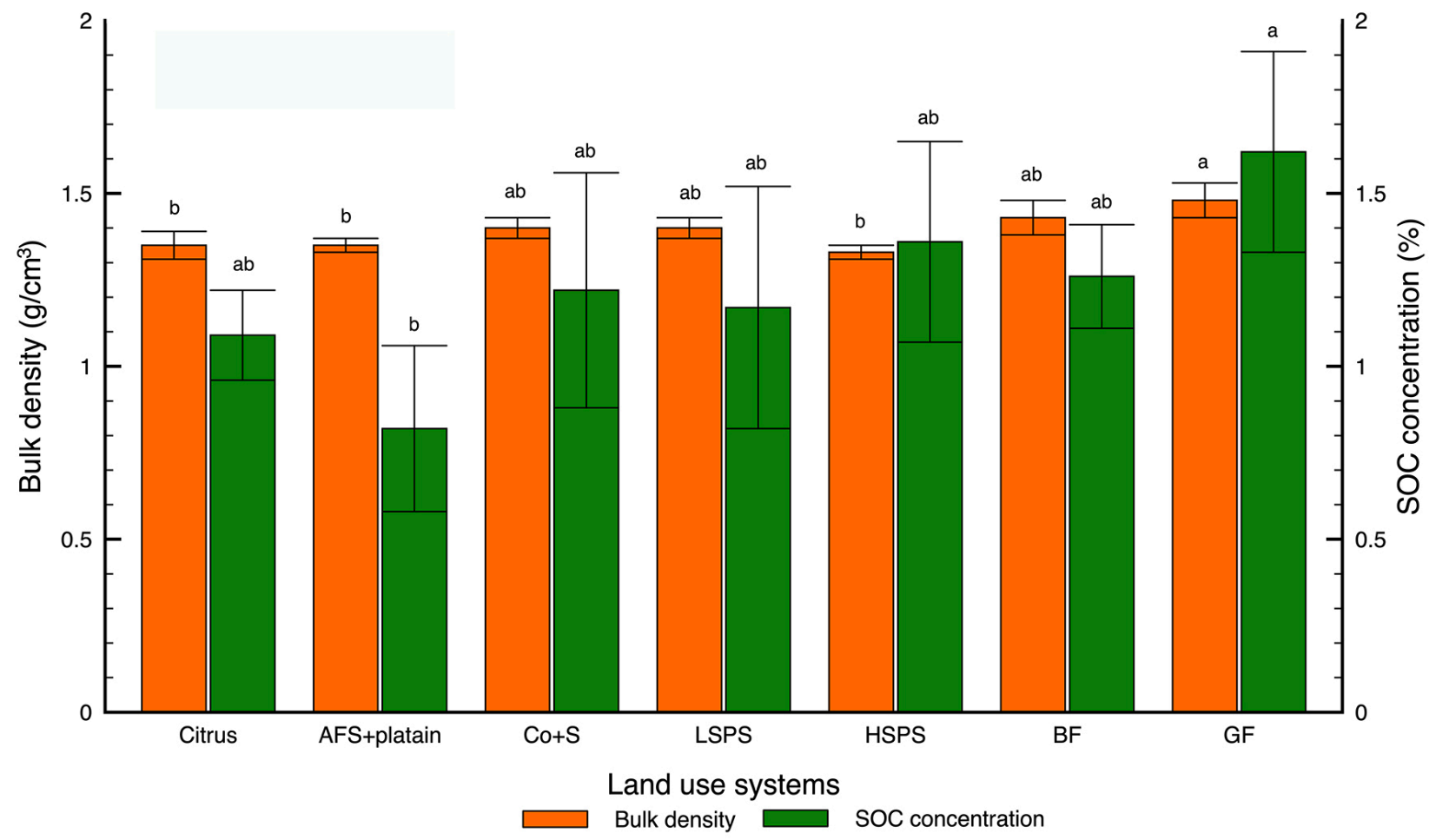

Figure 2. Bulk density and soil organic carbon (SOC) concentration in the land use systems of corregimiento of Tacarimena, municipality of Yopal. Error bars correspond to standard error. Means with common letter are not significantly different ( $\mathrm{p}>0.05)$. AFS + plantain: plantain with shade; Co+S: cocoa with shade; LSPS: low silvopastoral systems; HSPS: high silvopastoral systems; BF: bush forests; GF: gallery forests.

of GF, HSPS, and BF the ones with the highest concentration $(1.62,1.36$ and $1.26 \%$, respectively) (Figure 2$)$. On the other hand, $\mathrm{AFS}+$ plantain showed the lowest SOC concentration $(0.82 \%)$. Likewise, SOC concentration differed significantly between the AFS+ plantain and GF uses $(p<0.05)$, but these are similar $(\mathrm{p}>0.05)$, between C, LSPS, Co+S, BF, and HSPS (Figure 2).

Andrade-Castañeda et al. (2016) report an SOC concentration of $1.7 \%$ in soils of dry riparian forests of Tolima, which is coherent with the current estimates for GF. Cantú-Silva \& Yáñez Díaz (2018) reported SOC concentrations for bushes of $2 \%$; grasslands, $19 \%$; forest plantations, $1.7 \%$; and agricultural areas, $1.3 \%$, at depths between 5 and $30 \mathrm{~cm}$, in the municipality of Linares, in the state of Nuevo León, México; values that are similar to those found on the study of interest. On this current study, differences in SOC concentrations are attributed to the change of land use, caused by the development of mechanization and management activities, such as the application of supplies that deteriorate the vegetal cover and with it, carbon accumulation in productive systems. On the contrary, there are affectations in SOC percentage of BF and GF, thus improving their ability for carbon accumulation.

Organic carbon reserves in the soil. Statistical differences were detected $(\mathrm{p}<0.05)$ among the land use systems studied, which ranged between 33.4 and $72.7 \mathrm{Mg} \mathrm{C} /$ ha (Figure 3). GF showed the highest SOC reserves $(72.2 \pm 13.8 \mathrm{Mg} / \mathrm{ha})$; whereas $\mathrm{Co}+\mathrm{S}$ and $\mathrm{C}$ stored 50.6 and $43.9 \mathrm{Mg} / \mathrm{ha}$, respectively and silvopastoral systems had reserves between 49.2 and $54.1 \mathrm{Mg} \mathrm{C} /$ ha (Figure 3). Significant 
differences $(p<0.05)$ were found between the SOC reserves of GF and AFS+plantain. Meanwhile, C, LSPS, Co+S, BF, and HSPS stored similar values $(\mathrm{p}>0.05)$ and showed a range between 43.9 and $54.1 \mathrm{Mg} / \mathrm{ha}$. Mandal et al. (2020) state that agriculture is a dominant land use and that carbon sequestration under different agroecosystems is an important option to fight climate change.

Values found in the study are coherent with the reports by AndradeCastañeda et al. (2016) in dry riparian forests of Tolima, Colombia (65.6Mg C/ha). Ortiz et al. (2008) report SOC storage for AFS with Cordia alliodora and cocoa of $43-62 \mathrm{Mg} \mathrm{C} / \mathrm{ha}$; and Arce et al. (2008) estimated $32 \mathrm{Mg} \mathrm{C} /$ ha in these same systems in the area of Valles de Talamanca, in Costa Rica. Meanwhile, Poveda et al. (2013) report $47.5 \mathrm{Mg} \mathrm{C} / \mathrm{ha}$, a value similar to the results of this current study. Tree density in the systems studied by Arce et al. (2008) was of 676 trees/ha, with the highest number for shade individuals, which is consistent with the results on this study in $\mathrm{Co}+\mathrm{S}$, where it was found that it stored $50.6 \mathrm{Mg} \mathrm{C} / \mathrm{ha}$. SOC difference between AFS+plantain and GF is explained with the change in land use and the management activities performed on the first one. This management exposes soils to adverse conditions that cause SOC deterioration (Ussiri \& Lal, 2013). This does not happen with soils occupied by GF and BF, which are dedicated to hydric conservation and regulation, reason why continuous losses of SOC would not be expected (Cosentino \& Costantini, 2000).

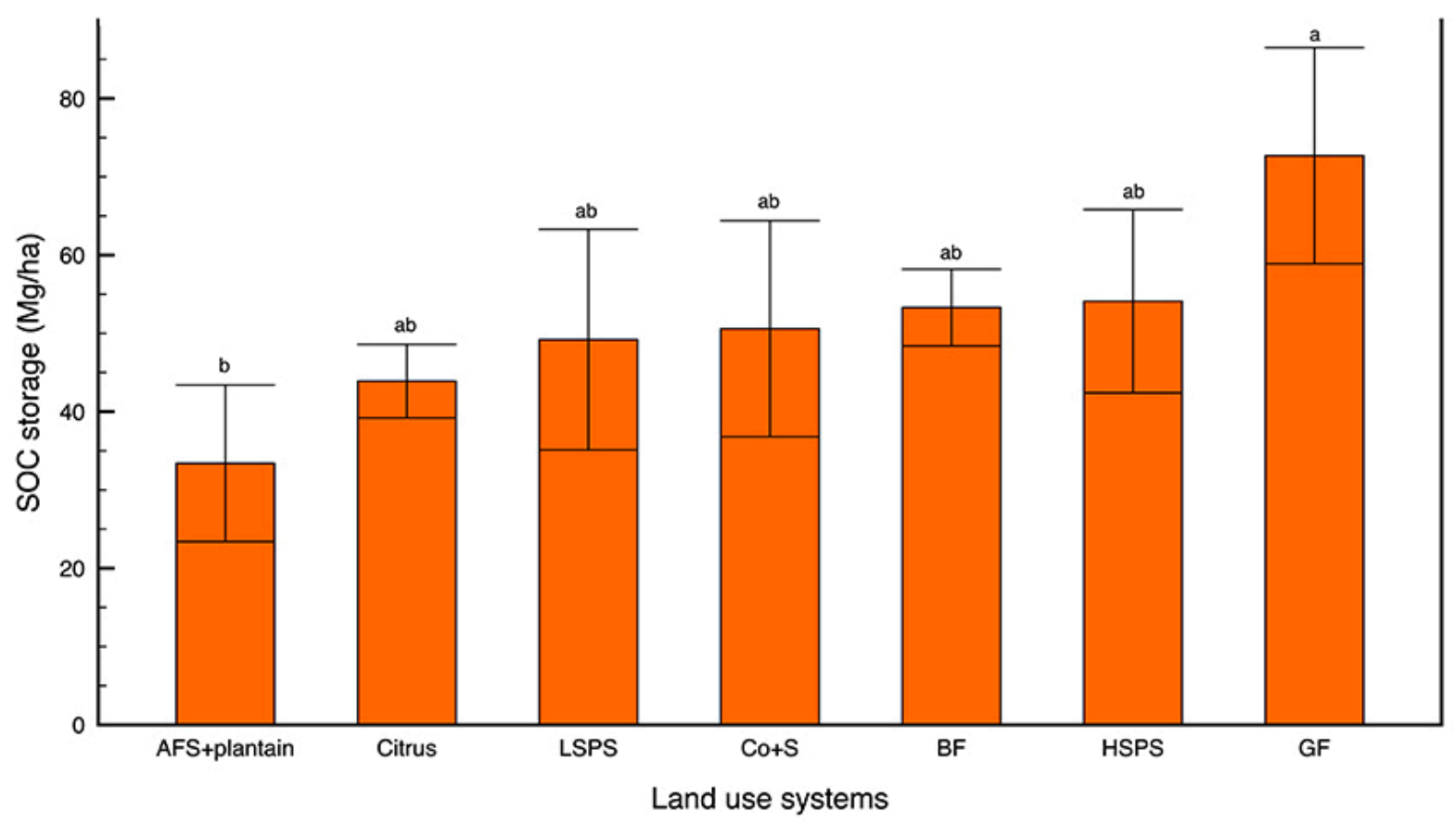

Figure 3. Soil organic carbon (SOC) storage in land use systems of corregimiento of Tacarimena, municipality of Yopal. Error bars correspond to standard error. Means with common letter are not significantly different $(\mathrm{p}>0.05)$. AFS + plantain: plantain with shade; LSPS: low silvopastoral systems; Co+S: cocoa with shade; BF: bush forests; HSPS: high silvopastoral systems; GF: gallery forests.

SOC dynamics is related to the changes of organic matter and its evolution, conditioned to variables such as vegetation (incorporation of residues due to plant decomposition), soil properties (texture, structure, clay mineralogy, and $\mathrm{PH}$ ), weather (temperature and humidity), which play a direct role in $\mathrm{C}$ incorporation and fixation (FAO, 2001). This process causes $\mathrm{C}$ storage, protected by fine particles, such as clay (Lal, 2012; Huang et al. 2014). Likewise, Rothon (2000) found a positive correlation between the stability percentage of aggregates and soil organic matter (SOM) content. Mathew et al. (2020) claim that SOC deposition is positively related to carbon translocation in the radicular zone.

SOC favors soil fertility and improves physical characteristics, since the particle aggregate improves pore distribution and the ability to retain and supply water to the plants. These features contribute to run-off reduction and susceptibility to drought (Lal, 2012).

Mineralization, lixiviation, and erosion cause around 20\% of global $\mathrm{CO}_{2}$ emissions (Intergovernmental Panel on Climate Change - IPCC, 2007), expressed in the following terms: "Variation of greenhouse gases (GHG) and aerosols in the atmosphere, and variations in earth cover and solar radiation, alter the energetic balance of the climate system." The most intense SOC losses take place in climates with high temperatures and humidity, like in the tropic (Crowther et al. 2016). This effect takes place in the area of interest in transient crop lands, given the climate conditions of Colombian lowlands, where altitudes below 400m, annual 
precipitation of $2,309 \mathrm{~mm}$, and average temperature of $26.9^{\circ} \mathrm{C}$, are the specific conditions given in the area of the study.

Effects of land use change in $\mathrm{C}$ fixation of $\mathrm{CO}_{2}$ emission. A reduction in SOC sequestration was when found tree cover is diminished, as in the change of GF and BF, on agricultural crops (Table 1). The most positive land use changes to mitigate climate change take place when AFS+ plantain moves to GF and HSPS, with additionalities of 130.3 and $88.0 \mathrm{Mg} \mathrm{CO} /$ ha, respectively (Table 1). In contrast, deforestation, to find areas for agricultural production, could cause emissions between 6.2 and $130.3 \mathrm{Mg} \mathrm{CO}_{2} /$ ha (Table 1). Several studies on land use changes in the Orinoquia region have detected alterations in SOC due to the conversion (Ramírez-Contreras et al. 2021), showing net carbon sequestrations or $\mathrm{CO}_{2}$ emissions (Rojas et al. 2018).

According to Ordóñez \& Masera (2001), and Valenzuela \& Visconti (2018), it is important to perform quantification studies of atmospheric carbon emission/sequestration in forest ecosystems or of land uses, with emphasis on the dynamics of land use change. This could permit estimation of carbon density associated to vegetation types and develop estimation and prediction methods for carbon emission or sequestration, under the dynamics of land use. Thus, GHG mitigation options could be offered in the short, medium, and long term. Meaning that carbon sequestration contributes to the mitigation of climate change.
In this context, Andrade-Castañeda et al. (2016) have studied and documented the potential impact due to land use changes, claiming that the biggest changes in SOC are held when pasture areas are changed into forest. On the other hand, when riparian forests are cut to establish rice fields, SOC tends to reduce, causing GHG emissions in $12.3 \mathrm{Mg} \mathrm{CO}_{2} / \mathrm{ha}$. In the semi-arid region of Brazil, Medeiros et al. (2020) found that conventional farming systems reduced SOC storage in the first meter of soil. In the basin of Combeima river, in Tolima, Colombia, Andrade et al. (2018) showed that land use systems without tree cover affect SOC through time. Likewise, Lozano Botache et al. (2011) claim that, currently, one of the main environmental problems addresses to coverage loss and, with it, to fragmentation of forests, alteration of soil resources; specifically, concerning erosion, to $\mathrm{CO}_{2}$ generation into the atmosphere, in terms of emissions.

The study allowed the assessment of how the land uses tested offer the ecosystem service of carbon storage intending to mitigate climate change. However, GF soils stored more SOC in contrast with AFS+plantain. HSPS is an important carbon sump that also allows cattle production at the same time.

Every use change would cause alterations in SOC storage. Land use changes that should be promoted to mitigate climate change can be moving from agricultural production systems to forest ecosystems, such as GF and BF. In silvopastoral systems, density increase of

Table 1. Potential impact on soil organic carbon storage by land use changes $\left(\mathrm{Mg} \mathrm{CO}_{2} / \mathrm{ha}\right)$, in el corregimiento of Tacarimena, municipality of Yopal - Casanare, Colombia.

\begin{tabular}{|c|c|c|c|c|c|c|c|c|}
\hline & \multicolumn{7}{|c|}{ Future land use } \\
\hline & & $\begin{array}{c}\text { AFS + } \\
\text { plantain } \\
(36,4 \mathrm{Mg} \\
\mathrm{C} / \mathrm{ha})\end{array}$ & $\begin{array}{c}\text { Citrus } \\
(48,4 \mathrm{Mg} \\
\mathrm{C} / \mathrm{ha})\end{array}$ & $\begin{array}{c}\text { LSPS } \\
(51,9 \mathrm{Mg} \\
\mathrm{C} / \mathrm{ha})\end{array}$ & $\begin{array}{c}\mathrm{Co}+\mathrm{S} \\
(54,2 \mathrm{Mg} \\
\mathrm{C} / \mathrm{ha})\end{array}$ & $\begin{array}{c}\mathrm{BF} \\
(55,9 \mathrm{Mg} \\
\mathrm{C} / \mathrm{ha})\end{array}$ & $\begin{array}{c}\text { HSPS } \\
(60,4 \mathrm{Mg} \\
\mathrm{C} / \mathrm{ha})\end{array}$ & $\begin{array}{c}\mathrm{GF} \\
(71,9 \mathrm{Mg} \\
\mathrm{C} / \mathrm{ha})\end{array}$ \\
\hline \multirow{7}{*}{ 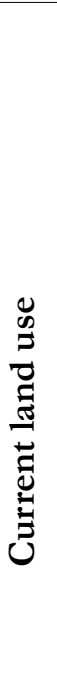 } & $\begin{array}{l}\text { AFS+plantain } \\
(36,4 \mathrm{Mg} \mathrm{C} / \mathrm{ha})\end{array}$ & - & 44.0 & 56.9 & 65.3 & 71.6 & 88.0 & 130.3 \\
\hline & $\begin{array}{l}\text { Citrus } \\
(48.4 \mathrm{Mg} \mathrm{C} / \mathrm{ha})\end{array}$ & -44.0 & - & 12.9 & 21.3 & 27.5 & 44.0 & 86.2 \\
\hline & $\begin{array}{l}\text { LSPS } \\
(51.9 \mathrm{Mg} \mathrm{C} / \mathrm{ha})\end{array}$ & -57.0 & -12.9 & - & 8.4 & 14.7 & 31.2 & 73.4 \\
\hline & $\begin{array}{l}\mathrm{Co}+\mathrm{S} \\
(54.2 \mathrm{Mg} \mathrm{C} / \mathrm{ha})\end{array}$ & -65.3 & -21.3 & -8.4 & - & 6.2 & 22.8 & 65.0 \\
\hline & $\begin{array}{l}\mathrm{BF} \\
(55.9 \mathrm{Mg} \mathrm{C} / \mathrm{ha})\end{array}$ & -71.6 & -27.5 & -14.7 & -6.2 & - & 16.5 & 58.7 \\
\hline & $\begin{array}{l}\text { HSPS } \\
(60.4 \mathrm{Mg} \mathrm{C} / \mathrm{ha})\end{array}$ & -88.0 & -44.0 & -31.2 & -22.8 & -16.5 & - & 42.2 \\
\hline & $\begin{array}{l}\text { GF } \\
(71.9 \mathrm{Mg} \mathrm{C} / \mathrm{ha})\end{array}$ & -130.3 & -86.3 & -73.4 & -65 & -58.7 & -42.2 & - \\
\hline
\end{tabular}

AFS+plantain: plantain with shade; LSPS: low silvopastoral systems; Co+S: cocoa with shade; BF: bush forests; HSPS: high silvopastoral systems; GF: gallery forests. 
tree component enhanced SOC storage, with the consequent additionality in this ecosystem service. Pasture improvement and tree cover increase AFS-intended, can introduce them with carbon storage potential at the area of study level, in addition to having forests that bring protection of hydric resources. Management measures for sumps and $\mathrm{CO}_{2}$ sources that increase sequestration in the first cases and reducing emission in the second are required, so that conversion of sumps into sources is avoided.

In general, production systems that involve trees in proper densities are suggested as a guarantee in carbon sequestration and, with this, offer the possibility of mitigating climate change. Given that soils studied are representative of the Orinoquia foothill, results could be extrapolated to this area, which would provide an estimate of the importance of these land uses and changes in this ecosystem service.

Acknowledgement. The authors thank the owners of the lands from the Corregimiento de Tacarimena, where all the information was taken, people who, without selflessly and unsuspectingly allowed the entrance of staff into their lands to collect the data. The authors also show their respect and admiration for Mr. Marco Polo Maldonado. Just the same, authors thank the Research Group (Grupo de Investigación) PROECUT from Universidad del Tolima, for their support on the statistical analysis and the time they offered in their facilities. Conflict of interest: The manuscript was prepared and revised with the participation of both authors, who hereby attest that there is no conflict of interest that may jeopardize the validity of the results in this study. Funding: The study was funded by the authors and it is part of the research results of the Master's Degree thesis of the first author.

\section{REFERENCES}

1. AGOSTINI, M.; MONTERUBBIANESI, M.; STUDDERT, G.; MAURET'TE, S. 2014. Un método simple y práctico para la determinación de densidad aparente. Cienc. Suelo. (Argentina). 32(2):171-176.

2. ALCALDÍA DE YOPAL. 2013. Acuerdo Municipal N024. "Por el cual se adopta el plan de ordenamiento territorial del municipio de Yopal”. Plan básico de ordenamiento territorial municipio de Yopal- Casanare. Concejo municipal de Yopal. (Colombia). 172p.

3. ALVARADO, J.; ANDRADE, H.J.; SEGURA., M.A. 2013. Almacenamiento de carbono orgánico en suelos en sistemas de producción de café (Coffea arabica L.) en el municipio del Líbano, Tolima, Colombia. Colombia Forestal. 16(1):21-31.

4. ANDRADE-CASTAÑEDA, H.J.; SEGURA-MADRIGAL, M.A.; ROJAS-PATIÑO, A.S. 2016. Carbono orgánico del suelo en bosques riparios, arrozales y pasturas en piedras, Tolima, Colombia. Agron. Mesoam. (Costa Rica). 27(2):233-241.

http://dx.doi.org/10.15517/am.v27i2.24359
5. ANDRADE, H.J.; MUÑOZ, J.; SIERRA, E.; GUTIÉRREZ, J.F.; CANAL, D.S. 2018. Propiedades físicas e hidrológicas en áreas con los usos del suelo dominantes en la microcuenca La Plata (Ibagué, Colombia). En: Andrade, H. (ed.). Servicios ecosistémicos aportados por sistemas de producción en laderas de la cuenca media del río Combeima (departamento del Tolima, Colombia): Un aporte hídrico a la gestión del recurso hídrico. Panamericana Formas e Impresos S.A. (Bogotá). p.63-78.

6. ARCE, N.; ORTIZ, E.; VILLALOBOS, M.; CORDERO, S. 2008. Existencias de carbono en charrales y sistemas agroforestales de cacao y banano de fincas indígenas Bribri y Cabécar de Talamanca, Costa Rica. Agroforestería en las Américas. (Costa Rica). 46(1):30-33.

7. BOLIN, B.; SUKUMAR, R. 2000. Global Perspective. In: Capturing carbon and conserving biodiversity. Cambridge University Press. (Cambridge. UK). p.23-51.

8. CANTÚ-SILVA, I.; YÁÑEZ DÍAZ, M.I. 2018. Efecto del cambio de uso del suelo en el contenido de carbono orgánico y de nitrógeno del suelo. Mexicana de Ciencias Forestales. 9(45):122-151. https://doi.org/10.29298/rmcf.v9i45.138

9. COSENTINO, D.J.; COSTANTINI, A.O. 2000. Evaluación de algunas formas de carbono como indicadores de degradación en argiudoles vérticos de Entre Ríos, Argentina. Rev. Facultad de Agronomía (UBA). (Buenos Aires-Argentina). 20(1):31-34.

10. CROWTHER, T.W.; TODD, K.E.; ROWE, C.W.; WIEDER, W.R.; CAREY, J.C.; MACHMULLER, M.B.; BRADFORD, M.A. 2016. Quantifying global soil carbon losses in response to warming. Nature. (Reino Unido). 540(1):104110 https://doi.org/10.1038/nature20150

11. GONZÁLEZ-MOLINA, L.; ETCHEVERS-BARRA, J.D.; HIDALGO-MORENO, C.1. 2008. Carbono en suelos de ladera: factores que deben considerarse para determinar su cambio en el tiempo. Agrociencia. (México). 42(7):741-751.

12. HUANG, S.; PAN, X.; GUO, J.; QIAN, CH.; ZHANG, W. 2014. Differences in soil organic carbon stocks and fraction distributions between rice paddies and upland cropping systems in China. Journal of Soils and Sediments. (Alemania). 14(1):89-98. https://doi.org/ 10.1007/s11368-013-0789-9

13. INSTITUTO DE HIDROLOGÍA, METEOROLOGÍA Y ESTUDIOS AMBIENTALES, IDEAM. 2018. Características climatológicas de ciudades principales y municipios turísticos. (Colombia). 48p. 
14. INSTITUTO GEOGRÁFICO AGUSTÍN CODAZZI, IGAC. 2003. Mapa de suelos de Colombia. Escala 1:500000. Memoria explicativa.

15. INSTITUTO GEOGRÁFICO AGUSTÍN CODAZZI, IGAC. 2014. Estudio General de suelos y zonificación de tierras Departamento de Casanare, escala 1: 100.000. Imprenta Nacional de Colombia. (Colombia). 423p.

16. INTERGOVERNMENTAL PANEL ON CLIMATE CHANGE, IPCC. 2007. Informe de síntesis. Ginebra, (Suiza). 104p.

17. LAL, R. 2012. Climate change and soil degradation mitigation by sustainable management of soils and other natural resources. Agricultural Research. 1(3):199-212. https://doi.org/10.1007/s40003-012-0031-9

18. LOZANO BOTACHE, L.A.; GÓMEZ AGUILAR, F.A.; VALDERRAMA CHAVES, S. 2011. Estado de fragmentación de los bosques naturales en el norte del departamento del Tolima. Tumbaga. (Colombia). 6(1):125140.

19. MANDAL, A.; MAJUMDER, A.; DHALIWAL, S.S.; TOOR, A.S.; MANI, P.K.; NARESH, R.K.; GUPTA, R.K.; MITRAN, T. 2020. Impact of agricultural management practices on soil carbon sequestration and its monitoring through simulation models and remote sensing techniques: A review. Critical Reviews in Environmental Science and Technology. (Netherlands). https://doi.org/10.1080/10643389.2020.1811590

20. MATHEW, I.; SHIMELIS, H.; MUTEMA, M.; MINASNY, B.; CHAPLOT, V. 2020. Crops for increasing soil organic carbon stocks - A global meta analysis. Geoderma, (Netherlands). 367:114230.

https://doi.org/10.1016/j.geoderma.2020.114230

21. MEDEIROS, A.S.; MAIA, S.M.F.; DOS SANTOS, T.C.; GOMES, T.C.A. 2020. Soil carbon losses in conventional farming systems due to land-use change in the Brazilian semi-arid region. Agriculture, Ecosystems \& Environment. (Netherlands). 287: 106690.

https://doi.org/10.1016/j.agee.2019.106690

22. MENDIETA, M.P. 2011. Estrategia Colombiana de Desarrollo Bajo en Carbono (ECDBC). Dirección de Cambio Climático. Ministerio de Ambiente y Desarrollo Sostenible. Bogotá. (Colombia). p.1-14.

23. ORDÓÑEZ, J.A.; MASERA, O. 2001. Captura de carbono ante el cambio climático. Madera y Bosques. (México). 7(1):3-12.
24. ORGANIZACIÓN DE LAS NACIONES UNIDAS PARA LA ALIMENTACIÓN Y LA AGRICULTURA, FAO. 2001. Agricultura y el cambio climático. Departamento de Agricultura y Protección del Consumidor. (Roma) Italia. $1 \mathrm{p}$

25. ORGANIZACIÓN DE LAS NACIONES UNIDAS PARA LA ALIMENTACIÓN Y LA AGRICULTURA, FAO. 2017. Carbono Orgánico del Suelo: el potencial oculto. Organización de las Naciones Unidas para la Agricultura y la alimentación y la agricultura. (Roma) Italia. 90p.

26. ORTIZ, A.; RIASCOS, L.; SOMARRIBA, E. 2008. Almacenamiento y tasas de fijación de biomasa y carbono en sistemas agroforestales de cacao (Theobroma cacao) y laurel (Cordia alliodora) Avances de Investigación. Agroforestería en las Américas. (Costa Rica). 46(1):26-29.

27. PEARSON, T.; WALKER, S.; BROWN, S. 2005. Sourcebook for land use, land-use change and forestry projects. Winrock International and the Biocarbon Fund of the World Bank. $57 \mathrm{p}$.

28. PEÑA, R.; RUBIANO, Y.; PEÑA, A.; CHAVÉS, B. 2009. Variabilidad espacial de los atributos de la capa arable de un Inceptisol del piedemonte de la cordillera Oriental (Casanare, Colombia). Agronomía Colombiana. (Colombia). 27(1):111-120.

29. POVEDA, V.; OROZCO, L.; MEDINA, C.; CERDA, R.; LÓPEZ, A. 2013. Almacenamiento de carbono en sistemas agroforestales de cacao en Waslala, Nicaragua. Avances de Investigación. Agroforestería en las Américas. (Nicaragua). 49(1):42-50.

30. RAMÍREZ-CONTRERAS, N.E.; MUNAR-FLOREZ, D.; HILST, F.V.D.; ESPINOSA, J.C.; OCAMPO-DURAN, Á.; RUÍZ-DELGADO, J.; MOLINA-LÓPEZ, D.L.; WICKE, B.; GARCIA-NUNEZ, J.A.; FAAIJ, A.P.C. 2021. GHG Balance of Agricultural Intensification \& Bioenergy Production in the Orinoquia Region, Colombia. Land (Switzerland). 10:289. https://doi.org/10.3390/land10030289

31. RIVERA, M.; AMÉZQUITA, E.; RAO, I.; CORRALES, I.; BERNAL, J. 2013. Sistemas agroforestales: Un enfoque integrado para el manejo sostenible de oxisoles de los Llanos Orientales de Colombia. Centro Internacional de Agricultura Tropical (CIAT). Cali. Colombia. 288p.

32. ROJAS, A.S.; ANDRADE, H.J.; SEGURA, M.A. 2018. Los suelos del paisaje alto-andino de Santa Isabel (Tolima, Colombia) ¿Son sumideros de carbono orgánico? Rev. U.D.C.A Act. \& Div. Cient. (Colombia). 21(1):51-59. https://doi.org/10.31910/rudca.v21.n1.2018.662 
33. ROTHON, F.E. 2000. Influencia del tiempo de respuesta del suelo a las prácticas de labranza cero. Soil Sci. Soc. Am. J. 64(2):700-709.

34. USSIRI, D.; LAL, R. 2013. The Role of Fertilizer Management in Mitigating Nitrous Oxide Emissions. In: Ussiri, D.; Lal, R. (eds). Soil Emission of Nitrous Oxide and Its Mitigation. Springer-Verlag, Berlin. p.315-346.

http://dx.doi.org/10.1007/978-94-007-5364-8_10

35. VALENZUELA B., I.G.; VISCONTI M., E.F. 2018. Influencia del clima, uso del suelo y profundidad sobre el contenido de carbono orgánico en dos pisos altitudinales andinos del departamento Norte de Santander, Colombia. Rev. Col. Ciencias Hortícolas. (Colombia). 12(1):233-243.

https://doi.org/10.17584/rcch.2018.v12i1.7349

36. WALKLEY, A.; BLACK, C.A. 1934. An examination of the Degtajareff's method for determining soil organic matter and a proposed modification of the chromic acid titration method. Soil Science. 37(1):29-38.

https://doi.org/10.1097/00010694-193401000-00003 